1955. Further observations on the seasonal cycle of Melosira italica (Ehr.) Kūtz. subsp. subartica O. Mull. J. Ecol. 49: 91-102.

1959. Buoyancy in relation to the ecology of freshwater phytoplankton. Br. Phyeot. Bull. 7, 17 pp.

Lund, J. W. G., Mackereth, F. J. H. \& Mortimer, C. H. 1963. Changes in depth and time of certain chemical and physical conditions and of the standing crop of Asterionella formosa Hass. in the North Basin of Windermere in 1947. Phil. Trans. R. Soc. 246B:255-90.

Malone, T. C., Garside, C. R. \& Roels, O. A. 1973. The possible occurrence of photosynthetic microorganisms in deep-sea sediments of the North Atlantic. J. Phycol. 9:482-8.

McLean, R.J. 1967. Desiccation and heat resistance of the green algae Spongiochloris ispica. Can. J. Bot. 45:1939-8.

1969. Rejuvenation of senescent celis of Spongiochloris typica. J. Phycol. 5:32-7.

Nipkow, F. 1950. Ruheformen planktischer Kieselalgen im geschicheten Schlamm des Zurichsees. Schuriz. Z. Hydrol. 12: 263-70.

Paerl, H. W. \& Stull, E. A. 1979. In defense of grain density autoradiography. Limnol. Oceanogr. 24:1 166-9.

Palmisano. A. C. \& Sullivan, C. W. 1982. Physiology of sea ice diatoms. I. Response of three polar diatoms to a simulated summer-winter transition. J. Phycol. 18:489-98.

Parker, B. C., Schanen. N. S. \& Renner, R. 1969. Viable soil algae from the herbarium of the Missouri Botanical Garden. Ann. Missouri Bot. Gard. 56:113-19.

Platt. T., Subba Rao, D. V., Smith, J. C., Li, W. K., Irwin, B., Horne, E. P. W. \& Sameoto, D. D. 1983. Photosynthetically- competent phytoplankton from the aphotic zone of the deep ocean. Mar. Ecol. Prog. Ser. 10:105-10.

Sandgren, C. D. 1989. Survival strategies of chrysophycean flagellates: reproduction and formation of resistant resting cysts. In Fryxell, G. A. [Ed.] Survival strategies of the algae. Cambridge University Press, New York, pp. 23-48.

Schlichting, H. E., Jr. 1974. Survival of some fresh-water algae under extreme environmental conditions. Trans. Amer. Micros. Soc. 93:610-3.

Simonsen, R. 1979. The diatom system: ideas on phylogeny. Bacillaria 2:9-71.

Smayda, T. J. \& Mitchell-Innes, B. 1974. Dark survival of autotrophic, planktonic marine diatoms. Mar. Biol. (Berl.) 25: 195-202.

Stockner, J. G. \& Lund, J. W. C. 1970. Live algae in post-glacial lake deposits. Limnol. Oceanogr. 15:41-58.

Vollenweider, R. A. (Ed.). 1974, A Manual on Methods for Measuring Primary Production in Aqualic Environments. 2nd Ed. IBP Handbook No. 12. Blackwell Scientific Publs, 225 pp.

von Stosch, H.-A. \& Fecher, K. 1979. "Internal thecae" of Eunotia solrirolii (Bacillariophyceae): Development, structure and function as resting spores. J. Phyrol. 15:239-43.

Wall, D., Guillard, R. R. L., Dale, B., Swift, E. \& Watabe, N. 1970. Calcite resting cysts in Peridinium trothoideun (Stein) Lemmermann, an autotrophic marine dinoflagellate. Phyco. login 9:151-6.

Webb, T., III. 1973. A comparison of modern and presettiemem pollen from southern Michigan (U.S.A.). Ret. Paleobot. Palyn. 16:137-56.

\title{
REJUVENATION OF MELOSIRA GRANULATA (BACILLARIOPHYCEAE) RESTING CELLS FROM THE ANOXIC SEDIMENTS OF DOUGLAS LAKE, MICHIGAN. II. ELECTRON MICROSCOPY'
}

\author{
Linda Sicko-Goad ${ }^{2}$
}

Great Lakes Research Division. The University of Michigan, Institute of Science and Technology, Ann Arbor, Michigan 48109

\section{ABSTRACT}

Detailed cytological changes that accompany the rejuzenation of resting cells of Melosira granulata were studied with the electron microscope. Dormant and viable cells that we previously classified as the condensed state generally contain definable chloroplasts, mitochondria, a nucleus and other cyloplasmic remnants. Howecter, there appears to be a continuous cytoplasmic degradation spectrum and some cells which appear intensely colored with the light microscope have discontinuous chloroplast membranes and few other cytoplasmic remnants. Rejuvenation of viable dormant cells is initially accompanied by the accumulation of both lipids and polyphosphates. In the earliest stages of expansion. these storage products are dispersed throughout the cell. In later stages of expansion, the lipids appear to be coalesced into larger droplets which are easily identified at the light microscope lecel. The fully

\footnotetext{
1 Accepted: 27 September 1985.

- Address for correspondence and reprints.
}

expanded stage is characterized by the normal complement of organelles and their arrangement at the periphery of the cells and central cyloplasmic bridge. These cells appear both anabolically and calabolically active as evidenced by the abundance of endoplasmic reticulum, ribosomes and secretory and lytic vesicles. Prior to cell division, both lipids and polyphosphates are reduced or absent in the cells. The ultrastructural features of the dormant, condensed state in resting cells of $M$. granulata are similar to those described for hypnospores. A rejuvenation sequence that produces cytological features common to resting slate formation could provide a population of cells which could easily revert should environmental conditions become adverse.

Key index words: diatom ultrastructure; Melosira; rejuvenation; resting cells

Although knowledge of the function and fate of resting spores of diatom populations has increased, little attention has been given to cells which function as a vegetative resting state. These resting cells differ 
from spores in several aspects. Spores can be more easily distinguished from vegetative cells in the light microscope by their external or frustular morphology. In some genera, resting spores resemble the parent vegetative cells. In others, spores and vegetative cells are morphologically dissimilar (Hargraves 1976, 1979). Generally spores are more heavily silicified than vegetagive cells (Hargraves and French 1983) or may possess frustular modifications such as the internal thecae described by von Stosch and Fecher (1979). Cells which are dormant but viable and have no known frustular modifications have been referred to as "physiologically resting cells" (Hargraves and French 1983). Perhaps because of the lack of differentiable morphology, the distribution and fate of resting cells have been studied very little. Malone et al. (1973) found that several species of pennate diatoms collected from red clay sediments in the North Atlantic bloomed when exposed to light at sea surface temperatures. Anderson $(1975,1976)$ studied the cytological and physiological characteristics of Amphora resting cells and found that the alga was capable of forming resting cells under adverse environmental conditions. These cells were also capable of reestablishing themselves under favorable growth conditions.

In our previous report (Sicko-Goad et al. 1986) we described with the light microscope cytological changes and ${ }^{14} \mathrm{C}$ uptake during the rejuvenation sequence of Melosira granulatn resting cells. The following report is a detailed description of the fine structural changes that delineate this ordered rejuvenation sequence.

\section{MATERIALS AND METHODS}

Ten and $20 \mathrm{~cm}$ sediment samples, roughly corresponding to 15 to 30 years burial in the sediment, were collected and processed as previously described (Sicko-Goad et al. 1986). Cell types were individually distinguished by light microscopy and selected for sectioning. All photographs were taken of sediment samples that had been resuspended in light for less than $104 \mathrm{~h}$. Thin sections of the epoxy-embedded material were cut with a diamond knife, collected on cleaned formvar coated 200 mesh copper grids and stained with aqueous uranyl acetate (Watson 1958). Sections were examined in a JEOL JEM $100 \mathrm{~B}$ electron microscope operating at $80 \mathrm{KV}$. Permanent epoxy mounts were also made from the osmicated samples as reference slides.

\section{RESULTS}

The ultrastructural differences between non-viable cells and cells which are in the condensed, dormant state appear to be minimal and can be best described as a continuous spectrum of degeneration. Our previous observations supported the assumption that the cell type containing dark brown cytoplasmic masses near the sulcus was the dormant condition. Individual cells in this state were identified in epoxy blocks sectioned and examined in the TEM. They were found to contain structures generally recognizable as chloroplasts, mitochondria, and oth- er cytoplasmic remnants (Fig. 1). However, the cytoplasm is intensely electron dense and few thylakoids or mitochondrial cristae are readily discernible. Examination of cells that were not as intensely stained and which we classified as containing non-viable cytoplasmic fragments revealed that these cells also contained similar organelles but appeared to be in a more advanced state of degradation (Figs. 2, 3). The non-viable cell population consisted of cells with a range of morphologies from the advanced degraded condition consisting for the most part of barely recognizable organelles (Fig. 2), to cells that resembled the condensed state. However, the cytoplasm is less electron-dense, fewer organelles are present, and the chloroplast membrane is not intact (Fig. 3).

Upon resuspension from the sediment and exposure to light, resting cells (condensed state) are quickly transformed to a more metabolically active and recognizable form that we have described as the partially expanded state (Figs. 4, 5). This state is characterized by the proliferation of cytoplasm and organelles in the sulcus region and along the cell periphery. The cytoplasm is less dense and occupies a greater portion of this region. The nucleus and nucleolus become more prominent (Fig. 4) and there is a proliferation of Golgi and its associated vesicles (Fig. 5). Chloroplasts and mitochondria increase in number and have recognizable thylakoids and cristae. Concomitant with the proliferation of cytoplasmic components there is also an increase in abundance of storage products, particularly polyphosphate and lipid. These storage products are not easily identified with the light microscope during the early expansion stage because of their small size (Fig. 5). The greatest number of cytological changes occur with hours of exposure to light.

The partially expanded state is a transient condition with usually no more than $2 \%$ of rejuvenating cells in this category (Sicko-Goad et al. 1986). These cells quickly differentiate into a cell type that is indistinguishable from vegetative populations. The single most noticeable change that occurs in the cells as cytoplasmic expansion continues is the accumulation of polyphosphates and lipids. These storage products, in many instances, occupy most of the cell volume (Fig. 6).

The fully expanded stage is characterized by the normal complement of organelles and arrangement at the periphery of the cell and central cytoplasmic bridge (Fig. 7). Endoplasmic reticulum becomes fairly abundant (Fig. 6). Vesiculation increases as cells approach the division state (Fig. 6). Several types of vesicles are common. One class of vesicles appears to be derived from the vacuole membrane (Fig. 8). These fully formed vesicles are found both in the cytoplasm and central vacuole. Frequently, autophagic-like vacuoles (Fig. 10) and inclusions resembling multivesicular-like bodies (Fig. 11) are found in fully mature cells. A third common vesicle type 

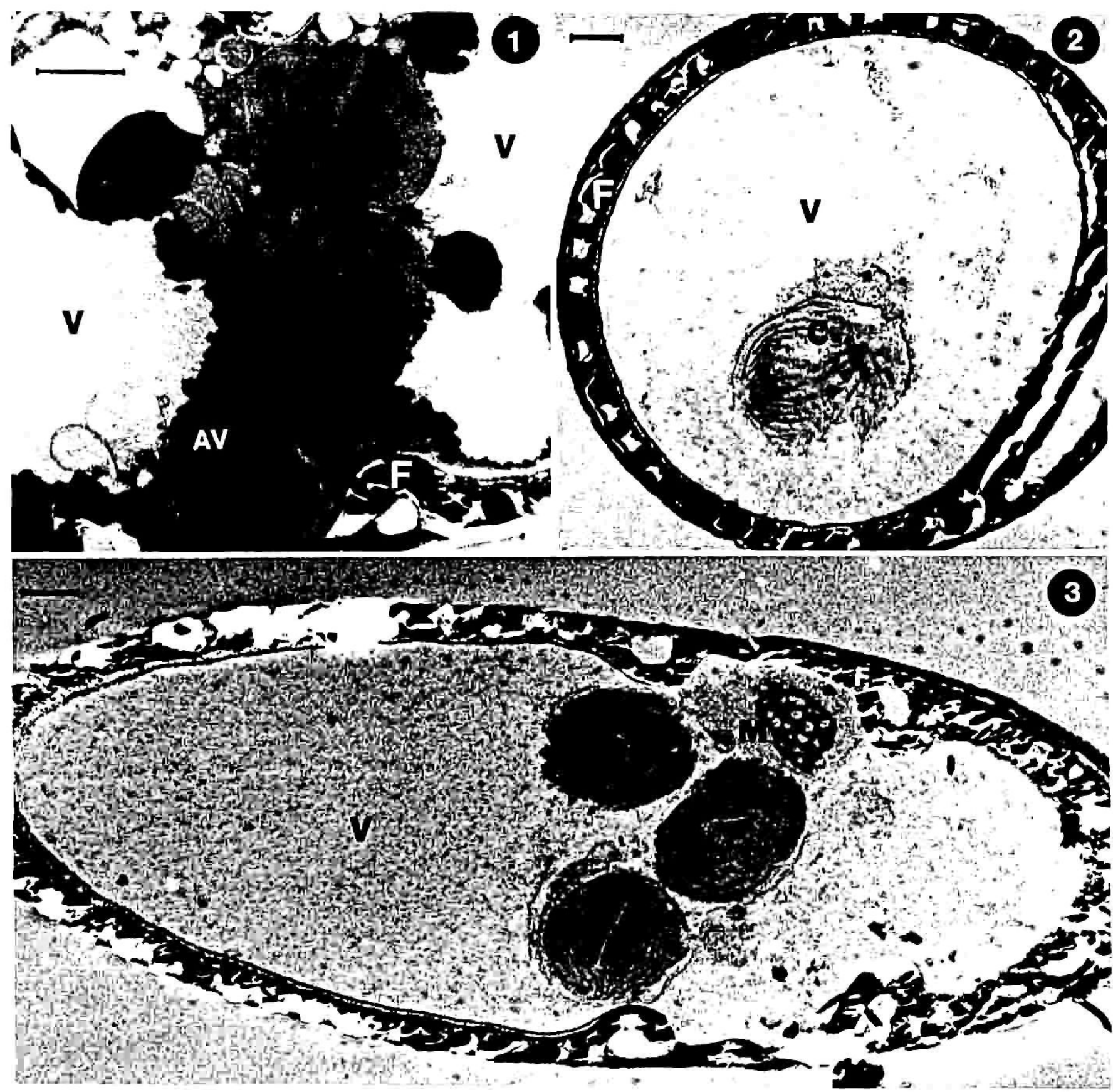

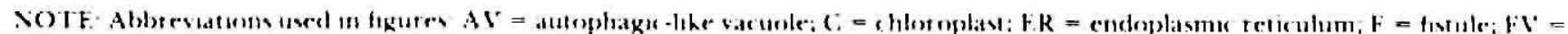

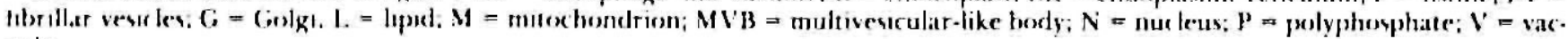
uoble

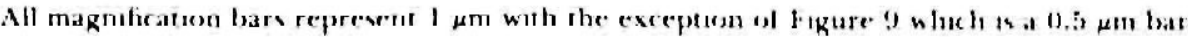

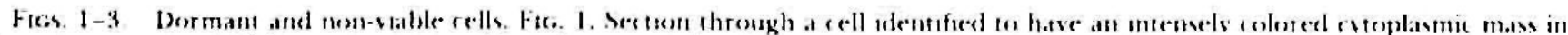

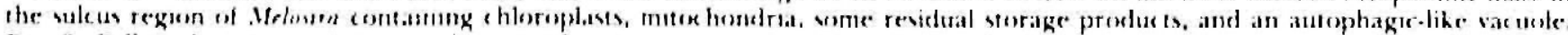

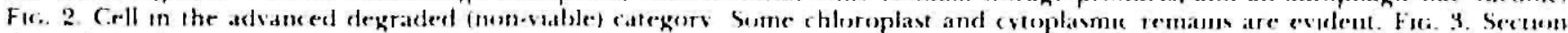

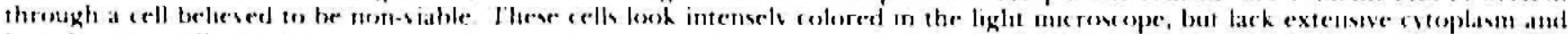
hate fen organelles present

is usualls found in cells just prior to and during divivion. This vesicle is ustalls found near the Golgi and its contents are characteried by a mottled elecetron opaque appearance and in some instances appears fibrillar (Figs. 9. 7). Prior to cell division the amounts of storage prosluess are greatly reduced.
Degraded polyphosphate bodies are found frequently in dividing cells (Figg. 12).

\section{DISC:USSION}

The most intriguing feature of resting cells is the apparent fue line that distingushes cytologically (and 


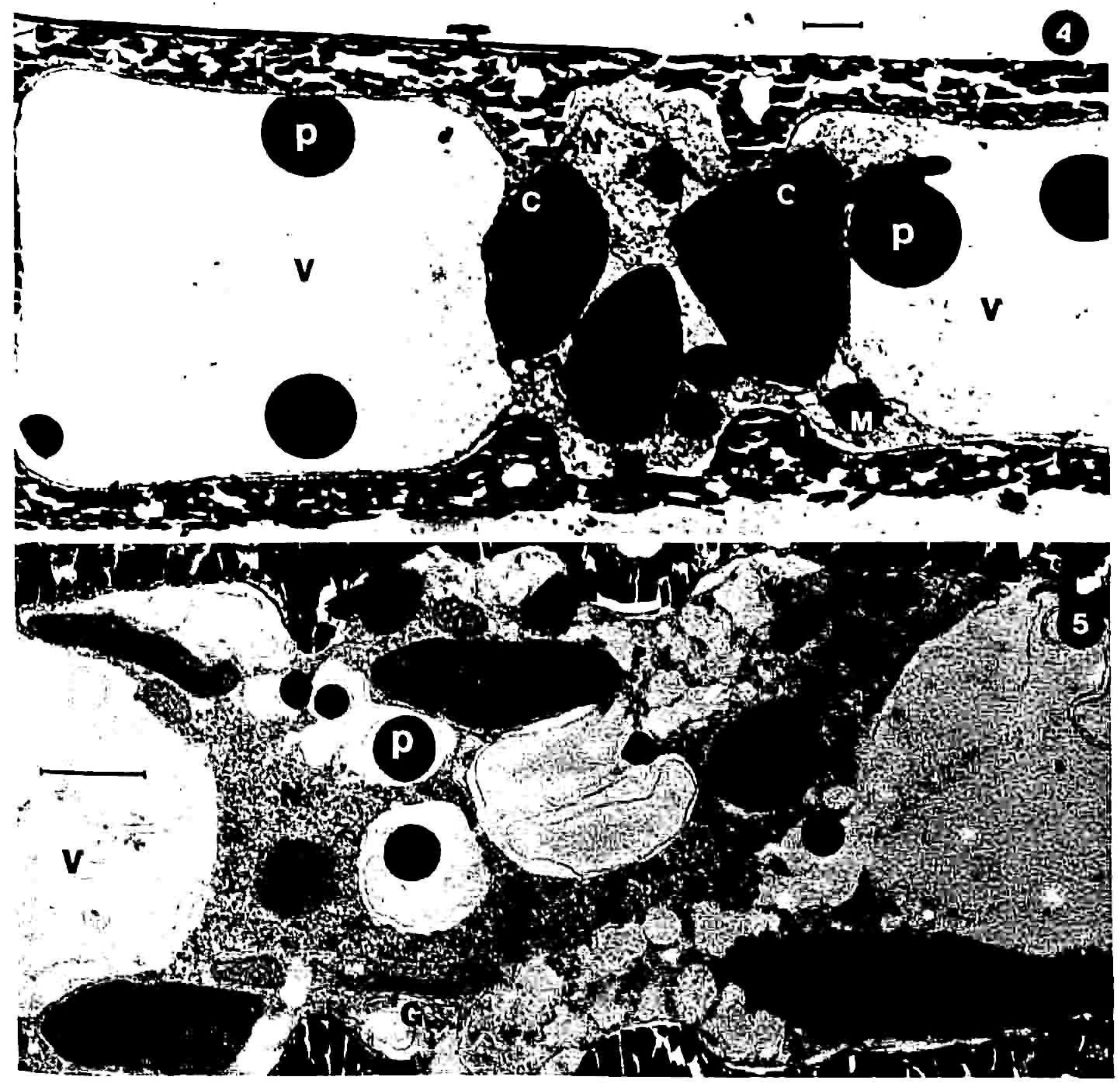

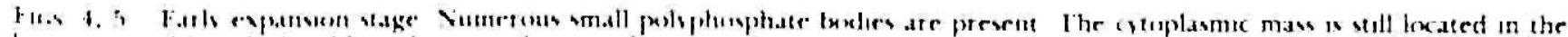

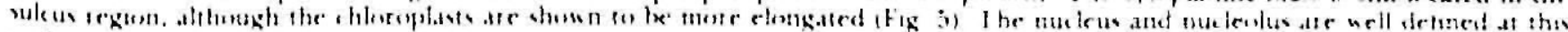
estls it.tige

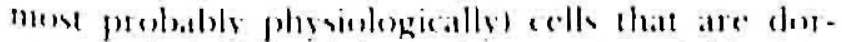
matut and viahle and those that .are mon-siable (i.e..

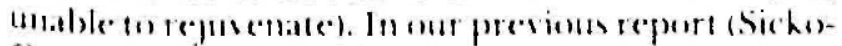

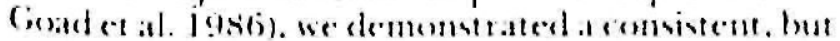

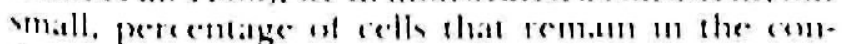

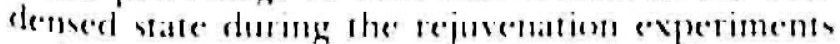
atel tre casils recognizable . It the light microsecope

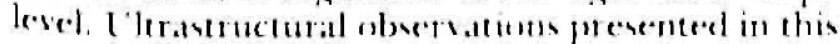

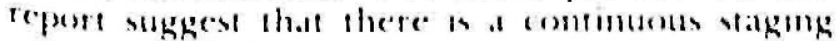

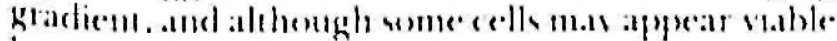

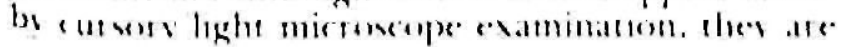

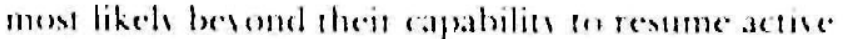
regetative gramsth

In terms of strvisal vrategies a stagmg gradiemt could be yuite atsantigeoms to speres which form revtlug cells rathes thath speres Resting spore formation ustalls repuires once or more sell disisum

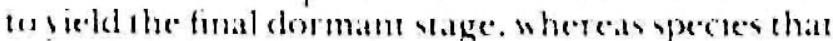
folm resting cells call for through the maximum number of cell alissens en sield greater numbers of pesemtiall dormant colls (Hargranes and Fremch

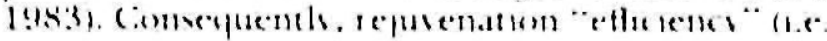



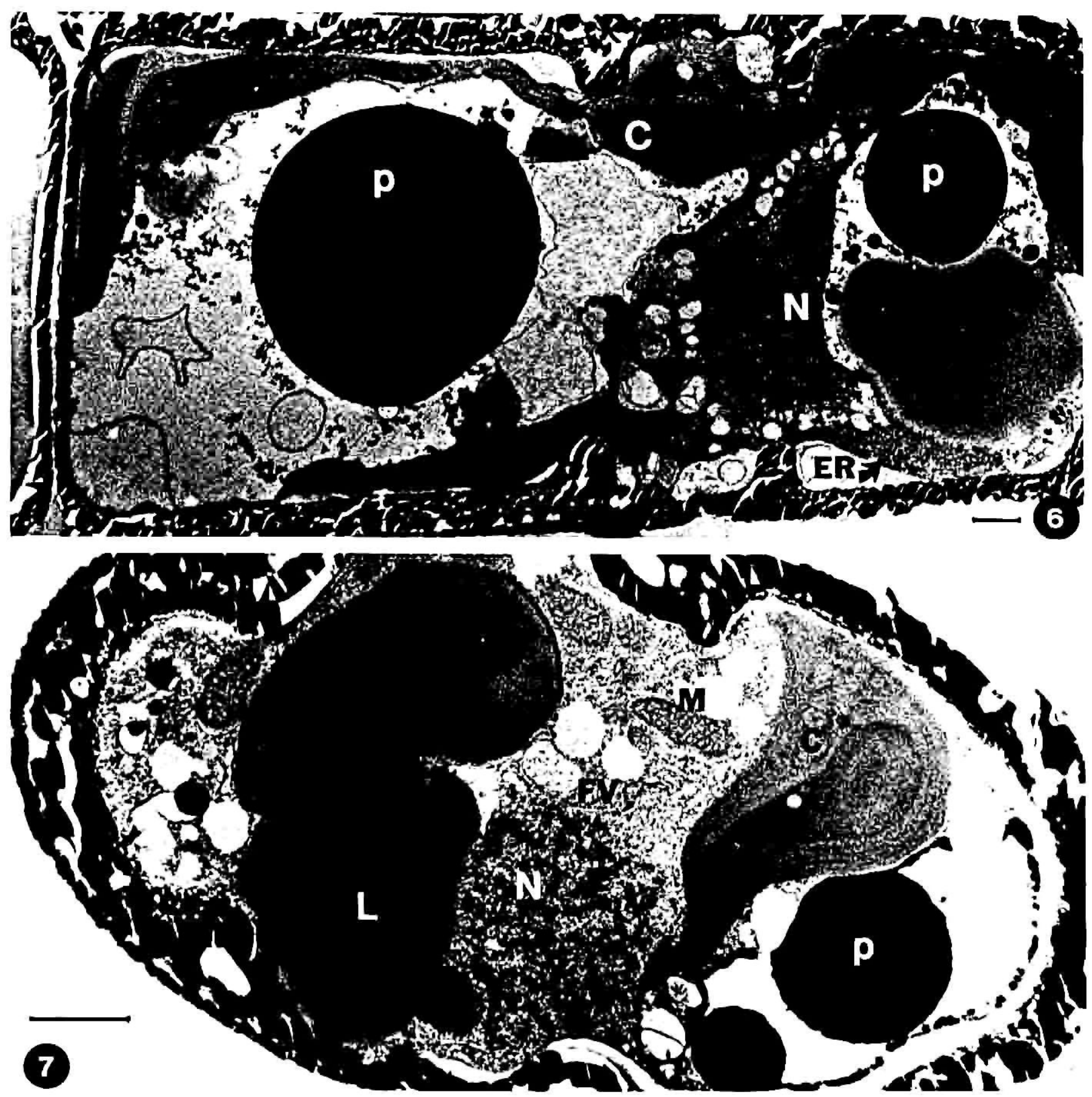

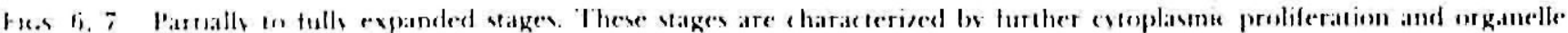

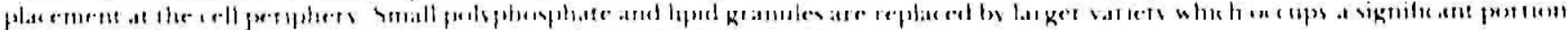

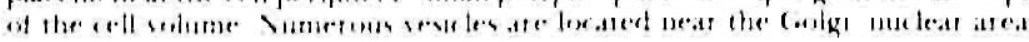

the number of celle wheh can rejusenate in a pupulations is less critscal. Similarls, staging is allors lews eritical, assumung that in at natural vetsing dormatt atls mas be the seed matertal fers sudelen and per. haps unexpected growh of certan pepulations.

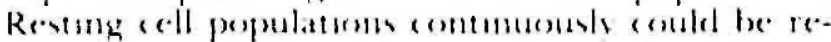

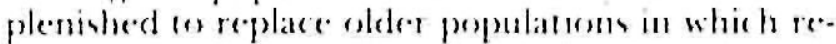

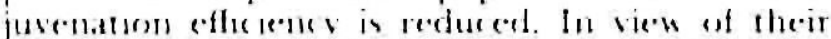

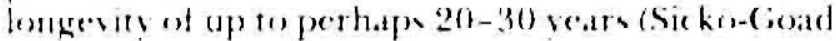

(2t. 1986), even if ne more resting colls were procluced, it is likely that a sediment mixing or perturbation phenomenes would ox cur that would bring restung cells back into favorable growth conditions.

The sudden onsee of storage preduct accumulatfion initialls was une xpected becaluse increases ate usually asseciated with unse ol adverse ensironmental parameterosuch as nut rient or toxicantestess

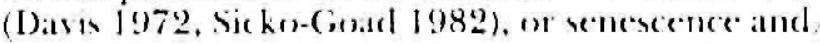



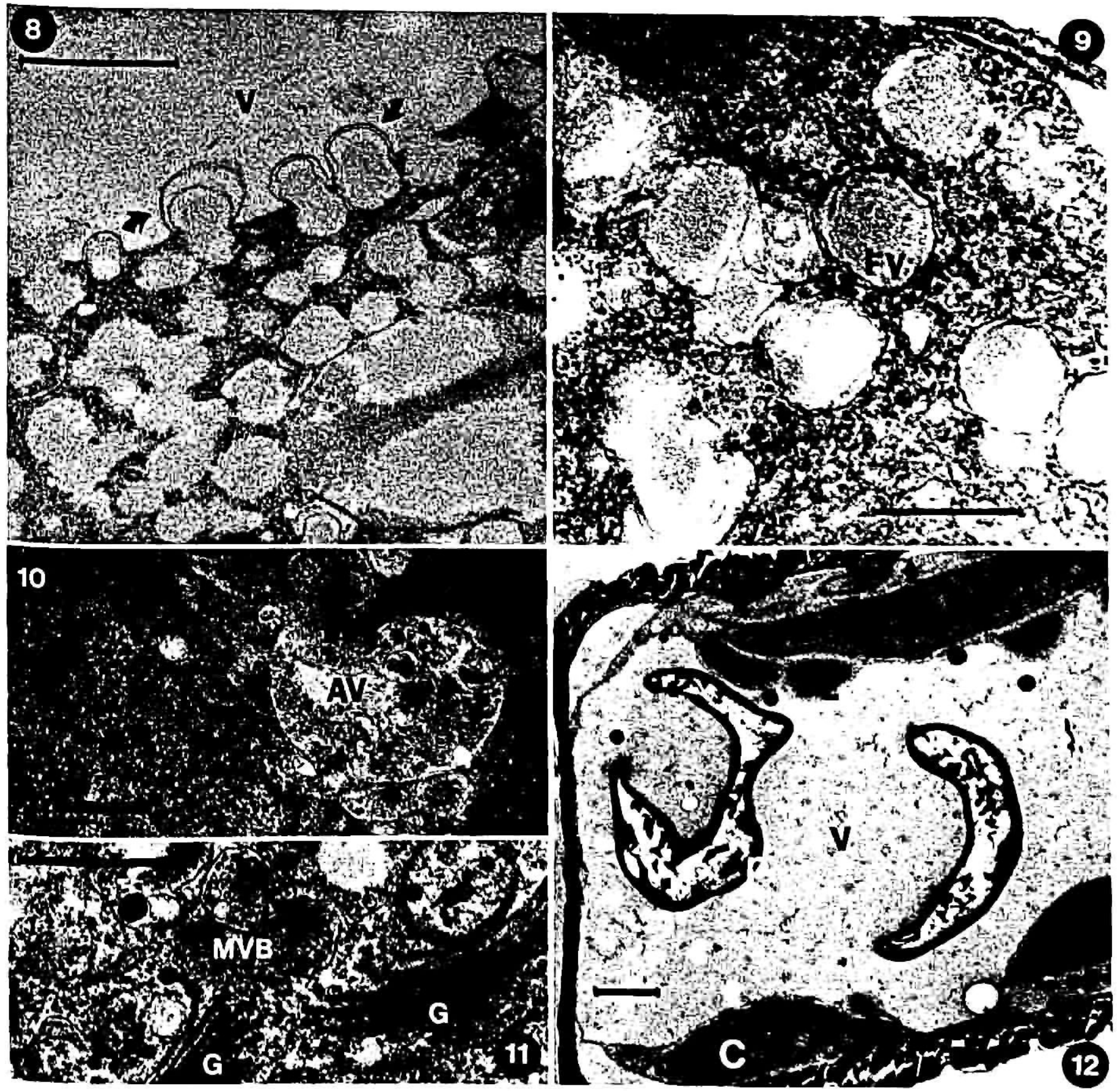

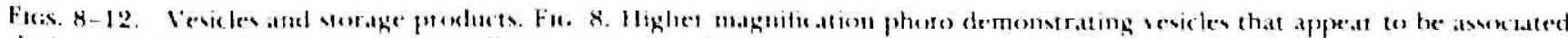

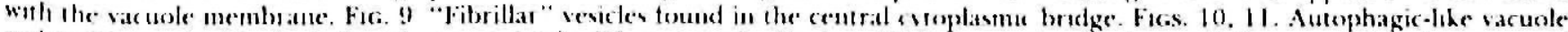

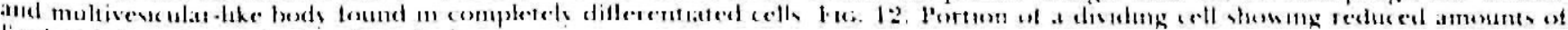

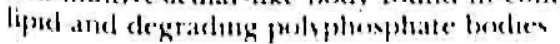

or spore formation (Netean J!) Sis. Shlichting 1974. Anderson 1975, vonsuseh and Fecher 1979. French and llargraves 1980 ). Hlowever. Bisalputrat and Antia (1980) demonst rated that reillumination of dark

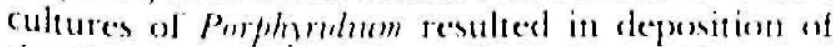
significamt numbers of statch grains within thres hours and they incerpret this ats indicative of earls restoration of photossuthetic capacios in cells that survive prolenged diarkness, The ${ }^{14} \mathrm{C}$ : uptake par- terms we reported for Melwera gramulata (Sicko-Cioad et al. 1986) alsosuggest that phoness nthetic capacits is restered earts and is vers high during rejusenation of .16. gramulata resting cells, The increase in storage product accumulation occurs at a point when the ectls are not completels differentiated but have well organized chloroplasts. It is conceisable that cells could use the serage products for their rapid burse of growth and resumption of the vegetative 
growth cycle. The formation of storage products during the initial stages of resting cell rejuvenation could also provide another survival strategy for $\mathrm{Me}$ losira. If the dormancy-rejuvenation sequence is indeed reversible, then formation of storage products at this early stage would provide additional seed populations for the formation of resting cells if environmental conditions should prove unfavorable for resumption of vegetative growth.

Another unusual cytological feature of rejuvenating cells is the great degree of vesiculation found in the expansion stage including the pre-division stage. Crawford (1973) described four types of small vesicles in Melosira varians. Three types were Golgi derived and were described as smooth, coated, and secretion vesicles. The fourth vesicle type, dense vesicles, were described as products of the nuclear envelope. Crawford frequently found what he termed vesicle complexes which we believe are similar to the structures we describe as multivesicularlike bodies (MVB). The presence of MVBs as well as residual bodies or autophagic-like vacuoles in $\mathrm{Me-}$ losira is not surprising in view of the tremendous metabolic activity associated with rejuvenation. The presence of both secretory and lytic vesicles merely indicates that both anabolic and catabolic activities are occurring simultaneously and need not be separated either spatially or temporally (Matile 1975). Indeed lytic activity is not just associated with formation of the resting stage and compaction and reorganization of cytoplasmic components.

The vesicles that appear prior to division and are fibrillar in nature have also been described in $\mathrm{Ca}$ loneis (Walker et al. 1979, Edgar 1980) and several other diatoms (Drum and Pankratz 1964, Stoermer et al. 1965, Taylor 1972). Although the fibrillar bundles appear in close association with the nuclear envelope in Caloneis (Walker et al. 1979), no direct evidence for their origination could be determined in Melosira, where the fibrous vesicles are usually located near the nucleus and Golgi.

The cytological transition between the dormant state and vegetative growth appears to be a continuous reversible gradient of both anabolic and catabolic activities. Features which are generally regarded as being indicative of the beginnings of senescence or dormancy are also associated with the rejuvenation process and general features of this reversible transition may be summarized as follows: (1) There is an accumulation of storage products prior to spore formation in many diatoms and during the rejuvenation sequence of resting cells before full resumption of vegetative growth; (2) There is extensive lytic activity prior to spore formation that most likely involves cytological compaction and conservation of essential organelles for entry into the dormant state. Likewise, during the rejuvenation sequence there is evidence of lytic activity which probably suggests remobilization of essential metab- olites for growth. The presence of lytic activity need not suggest a detrimental catabolic state.

Diatom survival strategies include the formation of resting states in both the form of hypnospores or resting cells whose frustule structure has not been modified. There are cytological similarities between the compact brown mass in both spores and resting cells. Additional features of the germination or rejuvenation of resting state cells that insure the persistence of diatom populations are both non-synchronous "germination" and formation of storage products and lytic vesicles. Non-synchronous germination insures that not all spores will germinate under adverse environmental conditions. A rejuvenation sequence that produces cytological features which are common to resting cell formation could provide a population of cells that could easily revert to a resting state.

Although resting cells have not been studied extensively, we have observed other populations of diatoms in the sediments of Douglas Lake and Lake Michigan which appear to have the capacity to rejuvenate from a resting cell. However, these diatoms do not appear to survive prolonged burial like $M e$ losira. It is likely that resting cells are common in many genera but have not been recognized.

I would like to acknowledge the technical assistance of D. Lazinsky, L. Kobeck, and C. Bourne. C. L. Schelske and E. F. Stoermer provided valuable comments about the manuscript. Supported by NSF Grant OCE 83-091 42. Contribution No. 492 of the Great Lakes Research Division.

Anderson, O. R. 1975. The ultrastructure and cytochemistry of resting cell formation in Amphora coffarformis (Bacillariophyceac). J. Phycol. 11:272-81.

1976. Respiration and photosynthesis during resting cell formation in Lamphora coffaeformis (Ag.) Kütz. Limnol. Orranogr. $21: 452-6$.

Bisalputra, T. \& Antia, N. J. 1980. Cytological mechanism underlying darkness survival of the unicellular red alga Porphyridium cruentum. Bot. Mar. 23:719-30.

Crawford, R. M. 1979. The protoplasmic ultrastructure of the vegetative cell of Melosirn varians C. A. Agardh. J. Phycol. 9: 50-61.

Davis, J. S. 1972. Survival records in the algae, and the survival role of certain algal pigments, fat, and mucilaginous substances. The Biologist 54:52-93.

Drum. R. W. \& Pankratz, H. S. 1964. Pyrennids, raphes and other fine structure in diatoms. Am. J. Bot. 51:405-18.

Edgar, L. A. 1980. Fine structure of Calonris a mphisbarna (Bacillariophyceac). J. Phycol. 16:67-72.

French, F. W. \& Hargraves, P. E. 1980. Physiological characteristics of plankton diatom resting spores. Mar. Biol. Lett. 1:185-95.

Hargraves, P. F. 1976. Studies on marine plankton diatoms. It. Resting spore morphology. J. Phycol. 12:118-28.

1979. Studies on marine plankton diatoms. IV. Morphology of Chastoceros resting spores. Nova Heduigia 64:99120.

Hargraves, P. E. \& French, F. W. 1983. Diatom resting spores: significance and strategies. In Fryxell, G. A. [F.d.] Surrixal Sirategies of the Algap. Cambridge University Press. New York. pp. $49-68$. 
Malone, T. C., Garside, C. R. \& Roels, O. A. 1979. The possible occurrence of photosynthetic microrrganisms in decp-sea sediments of the North Atlantic. J. Phycol. 9:482-8.

McLean, R. J. 1968. Uttrastructure of Spongiochloris typica during senescence. J. Phyrol, 4:277-89.

Matile, P. 1975. The Lytic Compartment of Plant Cells. Cell Biology Monographs, Vol, 1. Springer-Verlag, Wien, $183 \mathrm{pp}$.

Schlichting, H. E., Jr. 1974. Survival of some fresh-water algae under extreme environmental conditions. Trans. Am. Microse. Sor, 93:610-3.

Sicko-Goad. L. 1982. A morphometric analysis of algal response to low dose. short-term heavy metal exposure. Protoplasma $110: 75-86$.

Sicko-Goad, L., Stoermer, E. F. \& Fahnenstiel, G. 1986. Rejuvenation of Melosirn granulata (Bacillariophyceac) resting celts from the anoxic sediments of Douglas Lake, Mfichigan. I. Light microscopy and ${ }^{14} \mathrm{C}$ uptake. J. Phycal. 22:22-8.

Stoermer, E. F., Pankratz. H. S. \& Bowen, C. C. 1965. Fine structure of Amphipleurn pellucida. II. Cytoplasmic fine structure and frustule formation, Am. J. Bot. 52:1067-78.

Taylor, D. L. 1972. Ultrastructure of Cocconeis diminuta Pantocsek. Arch. Mikrobiol. 81:196-45.

von Stosch, H.-A. \& Fecher, K. 1979. "Internal thecae" of Eunotia soleirolii (Bacillariophyceae): development, structure and function as resting spores. J. Phycol. 15:233-49.

Walker, G. K., Sicko-Goad, L. \& Stoermer, E. F. 1979. An ultrastructural examination of the pennate diatom Caloneis amphisbarna. Microbios Letters 12:141-52.

Watson, M. L. 1958. Staining tissue sections for electron microsopy with heavy metals. J. Biophys. Biochem. Cyfol, 4:475-8.

\title{
IRRADIANCE, DAYLENGTH AND TEMPERATURE EFFECTS ON ZOOSPOROGENESIS IN COLEOCHAETE SCUTATA (CHAROPHYCEAE)
}

\author{
Linda E. Graham, ${ }^{2}$ James $M$. Graham and James $A$. Kranzfelder
}

Department of Botany, University of Wisconsin, Madison, Wisconsin 53706

\begin{abstract}
Using a factorial design, we investigated the effects of 150 different combinations of irradiance, daylength and temperature on zoosporogenesis in Coleochaete scutata. Analysis of zariance (ANOVA) revealed that irradiance and daylength did not signifirantly influence the response, but that temperature was highly significant. Exposure of thalli $1020^{\circ} \mathrm{C}$ for one to several day's is sufficient to induce zoospore production in C. scutata and seteral other northern temperature species of Coleochaete. Results of the factorial experiment correlate well with field obseriations on the seasonal occurrence of asexual reproduction in several Coleochaete species. A technique based on results of this factorial study is described for using zoospores to obtain morphologically normal, unialgal cultures of $\mathrm{Co}$ leochaete sp. It was concluded that the factorial approach to investigation of emironmental control of zoosporogenesis can be a powerful tool for understanding natural algal population dynamics, as well as controlling grouth and reproduction of algae in the laboratory.
\end{abstract}

Key index words; Coleochaete; irradiance; photoperiod; reproduction; temperature; zonsporogenesis

The green alga Coleochaete, a freshwater littoral epiphyte, is of considerable phylogenetic interest due to its presumed relationship to the ancestry of land plants (Graham 1984). In order to study this genus in detail it is desirable to have cultures of as many

\footnotetext{
Acrepled: 10 October 1985.

- Reprint requests.
}

species as possible. Eleven species of Coleochaete have been described (Printz 1964), but unialgal cultures of only two species (C. scutata and $C$. nitellarum) are generally available (ex. UTEX LB 610 and LB 1261, Starr 1978), and these are morphologically abnormal. Isolation of Coleocharte species is unusually difficult because field-collected thalli typically harbor a variety of tightly-attached epiphytes which can grow faster than Coleochaete under culture conditions, and overrun new isolates. The best technique for obtaining Coleochaete cultures thus appears to be zoospore isolation, but the conditions which promote zoosporogenesis in Colcochaele have not been determined previously. A factorial experimental approach has been successfully used to elucidate environmental control of zoosporogenesis in Cladophora glomerala (Hoffmann and Graham 1984) and Ulothrix zonata (Graham et al. 1985b). Here we report the results of a similar experiment designed to determine what effects the environmental factors of temperature, irradiance and photoperiod and their combinations might have on zoospore production in Coleochnete scutata. This information has been used to develop a technique for obtaining morphologically normal, unialgal isolates of various Coleochaete species.

\section{MATERIALS AND METHODS}

\footnotetext{
Collections of natural populations of Coleorharte and field temperature measurements were made during the growing season at Lake Tomahawk (Oneida Co., WI) (Coleochaete srutata, C. soluta and C. pulvinata), Fish Lake (Dane Co.. WI) (C. scutata, C. irre
} 
This document is a scanned copy of a printed document. No warranty is given about the accuracy of the copy. Users should refer to the original published version of the material. 